\title{
DETERMINAN PERILAKU SADARI PADA WANITA USIA SUBUR DI WILAYAH PUSKESMAS KUTA UTARA TAHUN 2017
}

\author{
Ketut Sri Astuti*, Komang Ayu Kartika Sari, Desak Putu Yuli Kurniati \\ Program Studi Kesehatan Masyarakat Fakultas Kedokteran Universitas Udayana \\ *Email: Tutik_27@yahoo.com
}

\begin{abstract}
ABSTRAK
Puskesmas Kuta Utara merupakan salah satu puskesmas perkotaan di Kabupaten Badung yang memiliki proporsi tertinggi (18,8\%) wanita usia subur positif tumor atau benjolan pada payudara. Hasil studi pendahuluan menunjukkan bahwa perilaku Periksa Payudara Sendiri (SADARI) pada wanita usia subur masih rendah. Tujuan penelitian untuk mengetahui determinan perilaku SADARI pada wanita usia subur di wilayah Puskesmas Kuta Utara. Penelitian analitik ini menggunakan pendekatan cross sectional yang dilakukan pada 62 sampel wanita usia subur melalui wawancara menggunakan kuesioner. Analisis data dilakukan secara univariat, bivariat (uji chi-square) dan multivariat (regresi logistik). Hasil penelitian menunjukkan bahwa sebagian besar (54,8\%) wanita usia subur melakukan perilaku SADARI dengan baik. Hasil uji chi square menunjukkan bahwa pendidikan ( $R P=$ 2,563; $p=0,003$; 95\%CI: 1,174-5,594), tingkat pengetahuan ( $\mathrm{RP}=2,143 ; p=0,003 ; 95 \% \mathrm{CI}: 1,208-3,801$ ), dan dukungan sosial ( $\mathrm{RP}=1,812 ; p=0,033 ; 95 \% \mathrm{CI}$ : 1,266-2,594) memiliki hubungan yang signifikan dengan perilaku SADARI pada wanita usia subur. Hasil analisis multivariat menunjukkan bahwa faktor yang berpengaruh terhadap perilaku SADARI adalah tingkat pengetahuan (AOR=6,107; $p=0,003 ; 95 \% \mathrm{CI}$ : 1,879-19,851) dan dukungan sosial $(\mathrm{AOR}=11,807 ; p=0,033 ; 95 \% \mathrm{CI}: 1,216-114,683)$. Simpulan dari penelitian ini yaitu tingkat pengetahuan dan dukungan sosial merupakan faktor yang berpengaruh terhadap perilaku SADARI. Petugas kesehatan diharapkan dapat meningkatkan pemberian komunikasi, informasi, edukasi (KIE) dan dukungan peer group, khususnya bagi kelompok wanita usia subur yang memiliki perilaku SADARI yang masih rendah. Penelitian selanjutnya diharapkan dapat memperdalam penelitian ini dengan menggunakan berbagai variabel yang belum diteliti.
\end{abstract}

Kata kunci: SADARI, Wanita Usia Subur, Kualitatif

\begin{abstract}
Kuta Utara Health Center is one of the health centers in urban areas of Badung Regency that has the highest proportion $(18,8 \%)$ of women of childbearing age who have positive breast tumors or lumps. The results of a preliminary study showed that the behavior of Breast Self-Examination (BSE) in women of childbearing age is still poor. The purpose of this study was to determine the determinants of BSE behavior in women of childbearing age in the North Kuta Health Center area. This analytic study used a cross sectional approach which was conducted on 62 samples of women of childbearing age through interviews using a questionnaire. Data was analysed using univariate, bivariate (chi-square test) and multivariate (logistic regression) analysis. The results showed that the majority $(54,8 \%)$ of women of childbearing age performed BSE behavior well. Chi-square test results showed that education $(P R=2,563 ; p=0,003 ; 95 \% C I: 1,174-5,594)$, level of knowledge $(P R=2,143 ; p=$ 0,003; 95\% CI: 1,208-3,801), and social support ( $\mathrm{PR}=1,812 ; \mathrm{p}=0,033 ; 95 \% \mathrm{CI}: 1,266-2,594)$ have a significant relationship with BSE behavior in women of childbearing age. Results of multivariate analysis showed that level of knowledge $(A O R=6,107 ; p=0,003 ; 95 \% C I: 1,879-19,851)$ and social support $(A O R=11,807 ; p=0,033 ; 95 \% C I$ : 1,216-114,683) were the determinants of BSE behavior. The conclusion of this research is level of knowledge and social support are factors that influence BSE behavior. Health workers are expected to improve the provision of information, education and communication (IEC) and also peer groups support, especially for groups of women of childbearing age who have poor BSE behavior. Further researcher is expected to deepen this research by using various variables that have not been studied.
\end{abstract}

Keywords: BSE, Women of childbearing age, Qualitative 


\section{PENDAHULUAN}

Kanker payudara dikenal sebagai salah satu penyakit yang paling sering menyerang kaum perempuan di dunia. Di Provinsi Bali, jumlah yang positif tumor/benjolan pada payudara terbanyak di kabupaten Badung yaitu 75 orang $(5,61 \%)$ dari 1.338 orang yang melakukan skrining kanker payudara dengan metode pemeriksaan payudara sendiri (SADARI) (Dinkes Provinsi Bali, 2015). Di wilayah Puskesmas Kuta Utara ditemukan $18,8 \%$ yang positif tumor/benjolan pada payudara dan merupakan proporsi tertinggi diantara puskesmas lainnya di kabupaten Badung (Dinkes Badung, 2015). Salah satu upaya yang bisa dilakukan untuk mendeteksi secara dini kanker payudara adalah dengan melakukan SADARI (Melda, 2008). Berdasarkan teori HBM yang dikembangkan Becker dikutip oleh Notoatmodjo (2014) menyebutkan bahwa rendahnya ataupun tingginya perilaku penerimaan individu terhadap usaha-usaha pencegahan penyakit disebabkan oleh empat variabel utama yaitu kerentanan yang dirasakan, keseriusan (keparahan) yang dirasakan, manfaat yang diterima dan rintangan (hambatan) yang dialami dalam tindakannya untuk melawan penyakitnya maupun hal-hal yang memotivasi tindakan tersebut atau isyarat untuk bertindak.

Hasil studi pendahuluan melalui wawancara yang dilakukan pada 10 orang wanita usia subur (WUS) diperoleh 40\% wanita usia subur (WUS) sudah melakukan perilaku SADARI, sedangkan $60 \%$ WUS belum melakukan perilaku SADARI. Berdasarkan gambaran diatas, dapat diketahui bahwa perilaku SADARI pada WUS masih rendah. Di Indonesia, terutama di luar Bali penelitian sejenis ini sudah banyak, namun di Bali masih terbatas. Berdasarkan fenomena diatas, perlu dilakukan penelitian mengenai determinan perilaku SADARI pada WUS di wilayah Puskesmas Kuta Utara.

\section{METODE}

Penelitian ini adalah penelitian analitik dengan pendekatan cross sectional, yang dilaksanakan di Wilayah Puskesmas Kuta Utara pada bulan Mei 2017. Populasi penelitian ini adalah WUS yang ada di wilayah Puskesmas Kuta Utara dengan jumlah sampel 62 orang. Pemilihan sampel dilakukan secara multistage random sampling. Data dikumpulkan dengan wawancara menggunakan kuesioner.

\section{HASIL}

Distribusi frekuensi karakteristik WUS dapat dilihat tabel 1, diketahui bahwa sebagian besar berumur $<40$ tahun $(67,7 \%), 69,4 \%$ berpendidikan tinggi, 56,5\% berpengetahuan baik, 85,5\% tidak mendapatkan dukungan sosial, 66,1\% memiliki persepsi mengenai risiko menderita kanker payudara (kerentanan), 91,9\% memiliki persepsi keseriusan yang tinggi, 90,3\% memiliki persepsi manfaat yang tinggi, 80,6\% memiliki persepsi hambatan yang kecil dan sebagian besar responden (54,8\%) berperilaku SADARI yang baik. 
Karakteristik Wanita $\mathrm{f}$

$\%$

Usia Subur

Umur (tahun)

$\geq 40$ tahun

20

32,3

$<40$ tahun

42

67,7

Pendidikan

Tinggi ( $\geq$ SMA)

43

69,4

Rendah (<SMA)

19

30,6

Tingkat pengetahuan

Baik

35

56,5

Kurang

27

43,5

Dukungan sosial

Ada dukungan

9

14,5

Tidak ada dukungan

53

85,5

Persepsi kerentanan

Rentan

41

66,1

Tidak rentan

21

Persepsi keseriusan

Tinggi

57

91,9

Rendah

5

8,1

Persepsi manfaat

Tinggi

56

90,3

Rendah

6

9,7 
Persepsi hambatan

Besar

Kecil

Perilaku SADARI

Baik

Hasil tabulasi silang dapat dilihat pada tabel 2, dimana hasil uji Chi Square diketahui secara statistik terdapat hubungan yang signifikan antara pendidikan $(p=0,003)$, pengetahuan $(p=0,003)$ dan dukungan sosial $(p=0,033)$ dengan perilaku SADARI pada WUS. Hasil analisis menunjukkan bahwa kelompok umur $\geq 40$ tahun menurunkan perilaku SADARI 0,875 kali lebih kecil dibandingkan dengan kelompuk umur tahun menurunkan perilaku SADARI 0,875 kali lebih kecil dibandingkan dengan kelompuk umur $<40$ tahun dan responden yang memiliki persepsi hambatan yang besar menurunkan perilaku SADARI 0,9 kali lebih kecil dibandingkan dengan responden yang memiliki persepsi hambatan yang kecil dalam melakukan perilaku SADARI. Responden yang berpendidikan tinggi akan meningkatkan perilaku SADARI 2,6 kali lebih besar dibandingkan dengan responden yang berpendidikan rendah, responden yang memiliki tingkat pengetahuan baik akan meningkatkan perilaku SADARI 2,1 kali lebih besar dibandingkan dengan responden yang memiliki tingkat pengetahuan kurang, responden yang memiliki dukungan sosial akan meningkatkan perilaku SADARI 1,8 kali lebih besar dibandingkan dengan responden yang tidak memiliki dukungan sosial, responden yang memiliki persepsi kerentanan akan meningkatkan perilaku SADARI 1,7 kali lebih besar dibandingkan dengan responden yang tidak memiliki persepsi kerentanan, responden yang memiliki persepsi keseriusan yang tinggi meningkatkan perilaku SADARI 1,4 kali lebih besar dibandingkan dengan responden yang memiliki persepsi keseriusan yang rendah tentang kanker payudara, dan responden yang memiliki persepsi manfaat yang tinggi dapat meningkatkan perilaku SADARI 1,7 kali lebih besar dibandingkan dengan responden yang memiliki persepsi manfaat yang rendah terhadap perilaku SADARI. 


\begin{tabular}{lllll}
\hline Variabel & Perilaku SADARI & RP & $95 \% \mathrm{CI}$ & p-value \\
\cline { 2 - 3 } & Baik Kurang & & \\
\hline
\end{tabular}

Karakteristik

Sosiodemografi

Umur

$\geq 40$ Tahun

$10(50,0 \%) \quad 10(50,0 \%)$

$0,875 \quad 0,525-1,458$

0,597

$<40$ Tahun

$24(57,1 \%) \quad 18(42,9 \%)$

Pendidikan

Tinggi ( $\mathrm{SMA}$ )

$29(67,4 \%) \quad 14(32,6 \%)$

$2,563 \quad 1,174-5,594$

0,003

Rendah (<SMA)

$5(26,3 \%) \quad 14(73,7 \%)$

Pengetahuan

Baik $25(71,4 \%) \quad 10(28,6 \%)$

$2,143 \quad 1,208-3,801$

0,003

Kurang

$9(33,3 \%) \quad 18(66,7 \%)$

Dukungan Sosial

Ada dukungan

$8(88,9 \%) \quad 1(11,1 \%)$

$1,812 \quad 1,266-2,594$

0.033

Tidak ada dukungan

$26(49,1 \%) \quad 27(50,9 \%)$

Persepsi kerentanan

Rentan

$26(63,4 \%) \quad 15(36,6 \%)$

1,665

$0,920-3,011$

0,058

Tidak Rentan

$8(38,1 \%) \quad 13(61,9 \%)$

Persepsi keseriusan

Tinggi

$32(56,1 \%) \quad 25(43,9 \%)$

$1,404 \quad 0,468-4,207$

0,650

Rendah

$2(40,0 \%) \quad 3(60,0 \%)$ 
Persepsi manfaat
Tinggi
$32(57,1 \%)$
$24(42,9 \%)$
$1,714 \quad 0,541-5,436$
0,396
Rendah
$2(33,3 \%) \quad 4(66,7 \%)$
Persepsi hambatan
Besar
$6(50,0 \%) \quad 6(50,0 \%)$
0,893
$0,482-1,655$
0,708
Kecil
$28(56,0 \%) \quad 22(44,0 \%)$

Pada tahap analisis multivariat, faktor yang berpengaruh terhadap perilaku SADARI adalah tingkat pengetahuan $(p=0,003$, $\mathrm{AOR}=6,107)$ dan dukungan sosial $(p=0,033$, $\mathrm{AOR}=11,807$ ). Jadi responden yang memiliki tingkat pengetahuan baik berpeluang 6,1 kali lebih besar untuk melakukan perilaku
SADARI dibandingkan dengan responden yang memiliki tingkat pengetahuan kurang dan responden yang ada dukungan sosial memiliki peluang 11,8 kali lebih besar untuk melakukan perilaku SADARI dibandingkan dengan responden yang tidak ada dukungan sosial.

Tabel 3. Hasil analisis multivariat antara variabel-variabel yang potensial terhadap perilaku SADARI

\begin{tabular}{lccc}
\hline Model & AOR & $95 \%$ CI & $p$-value \\
\hline Model 1 & 2,915 & $0,742-11,447$ & 0,125 \\
Pendidikan & 3,846 & $1,062-13,936$ & 0,040 \\
Pengetahuan & 2,022 & $0,460-8,892$ & 0,352 \\
Persepsi kerentanan & 12,845 & $1,113-148,237$ & 0,041
\end{tabular}

Model 2

Pendidikan

3,472

$0,932-12,937$

0,064

Pengetahuan

4,614

$1,345-15,833$

0,015 
Dukungan sosial

9,791

$0,943-101,703$

0,056

Model 3

Pengetahuan

6,107

$1,879-19,851$

0,003

Dukungan sosial

11,807

$1,216-114,683$

0,033

Hasil output goodness of fit diperoleh bahwa data fit dengan model regresi logistik yang digunakan $(p=0,869)$ dan sebesar $30,1 \%$ kontribusi variabel pengetahuan dan dukungan sosial terhadap perilaku SADARI sedangkan sisanya 69,9\% ditentukan oleh variabel lain.

\section{DISKUSI}

Hasil penelitian menunjukkan bahwa sebagian besar responden (54,8\%) berperilaku SADARI yang baik, proporsi WUS yang memiliki prilaku SADARI baik terbanyak ada pada usia $<40$ tahun yakni $67,7 \%$, dan sebnyak $69,4 \%$ memiliki tingkat pendidikan yang tinggi. Penelitian ini juga menunjukkan bahwa tidak terdapat hubungan yang signifikan antara umur dengan perilaku SADARI. Responden pada kelompok WUS umur $\geq 40$ tahun kemungkinan untuk melakukan SADARI hanya 0,875 kali dibandingkan dengan responden pada kelompuk umur $<40$ tahun. Menurut Nursalam (2008), seseorang pada umur muda cenderung memiliki daya ingat lebih kuat, keinginan dan semangat yang tinggi untuk maju demi masa depan yang lebih baik sehingga mereka lebih aktif dalam mencari informasi maupun menerima informasi yang dapat menambah pengetahuan mereka.

Dilihat dari pendidikan, hasil uji statistik Chi Square menunjukkan bahwa terdapat hubungan yang signifikan antara pendidikan dengan perilaku SADARI pada WUS. Responden yang memiliki pendidikan lebih tinggi akan meningkatkan perilaku untuk melakukan SADARI 2,6 kali lebih besar dibandingkan dengan responden yang memiliki pendidikan lebih rendah SMA. Sejalan dengan penelitian Darmasari (2016) menyatakan terdapat hubungan yang signifikan antara tingkat pendidikan dengan perilaku SADARI di Kelurahan Tambak Rejo Kecamatan Gayamsari Kota Semarang. Nursalam (2008) menyatakan semakin tinggi pendidikan seseorang maka tingkat pemahaman serta kepedulian untuk berperilaku terhadap suatu hal akan cenderung semakin tinggi atau positif. Oleh karena itu, semakin tinggi tingkat pendidikan seseorang, maka diharapkan semakin tinggi pula pengetahuan tentang SADARI serta semakin positif pula perilaku SADARI-nya.

Sebagian besar WUS berpengetahuan baik tentang SADARI (56,5\%), tapi masih ada $43,5 \%$ WUS yang berpengetahuan kurang. Hal ini mungkin disebabkan oleh kurangnya informasi, pemahaman yang salah tentang SADARI dan kurangnya kemauan WUS untuk mencari dan menggali informasi sendiri sehingga mengakibatkan kurangnya pengetahuan WUS tentang SADARI. Oleh karena itu, perlu adanya peningkatan KIE 
secara optimal. Dari hasil penelitian ini diketahui bahwa secara statistik terdapat hubungan yang signifikan antara pengetahuan dengan perilaku SADARI pada WUS. Responden yang memiliki tingkat pengetahuan baik tentang SADARI akan meningkatkan perilaku untuk melakukan SADARI sebesar 2,1 kali lebih besar dibandingkan dengan seseorang yang memiliki tingkat pengetahuan kurang. Menurut Notoatmodjo (2007), tingkat pengetahuan yang tinggi tentang kanker payudara akan cenderung membentuk perilaku yang positif.

Hasil analisis menunjukkan sebagian besar $(85,5 \%)$ responden tidak mendapatkan dukungan sosial untuk berperilaku SADARI, 66,1\% responden memiliki persepsi kerentanan, 91,9\% memiliki persepsi keseriusan yang tinggi, 90,3\% memiliki persepsi manfaat yang tinggi dan $80,6 \%$ responden memiliki persepsi hambatan yang kecil dalam melakukan perilaku SADARI. Berdasarkan hasil penelitian ini, diketahui secara statistik terdapat hubungan yang signifikan antara dukungan sosial $(p=0,033)$ dengan perilaku SADARI pada wanita usia subur (WUS). Hasil analisis menunjukkan bahwa seseorang yang mendapat dukungan sosial akan meningkatkan perilaku untuk melakukan SADARI sebesar 1,8 kali lebih besar dibandingkan dengan seseorang yang tidak mendapatkan dukungan sosial. Sesuai dengan teori Health Belief Model yang menyatakan bahwa adanya isyarat untuk bertindak yaitu berupa dukungan sosial akan meningkatkan perilaku seseorang untuk lebih peduli terhadap kesehatannya. Menurut Kusumadewi (2012), dukungan sosial dapat berasal dari berbagai sumber, salah satunya peer group atau kelompok teman sebaya.

Berdasarkan hasil analisis diketahui bahwa seseorang yang memiliki persepsi risiko menderita kanker payudara (kerentanan) akan meningkatkan perilaku untuk melakukan SADARI 1,7 kali lebih besar dibandingkan dengan seseorang yang tidak memiliki persepsi risiko menderita kanker payudara (kerentanan). Individu yang memiliki persepsi bahwa dirinya memiliki risiko menderita kanker payudara akan melakukan tindakan pencegahan dengan melakukan SADARI (Notoatmodjo, 2014).

Dari hasil analisis diperoleh tingginya persepsi keseriusan akan meningkatkan perilaku WUS untuk melakukan SADARI 1,4 kali lebih besar dibandingkan dengan responden yang memiliki persepsi keseriusan yang rendah tentang kanker payudara. Hasil penelitian ini sejalan dengan hasil penelitian yang dilakukan oleh Desanti (2008) yang mendapatkan hasil bahwa tidak terdapat hubungan yang signifikan antara persepsi keseriusan terhadap kanker payudara dengan perilaku SADARI.

Dari hasil analisis diketahui tingginya persepsi manfaat yang dirasakan meningkatkan perilaku untuk melakukan SADARI sebesar 1,7 kali lebih besar dibandingkan dengan responden yang memiliki persepsi manfaat yang rendah terhadap perilaku SADARI. Hasil analisis menunjukkan bahwa responden yang memiliki persepsi hambatan yang besar memiliki kemungkinan untuk melakukan perilaku SADARI 0,9 kali dibandingkan dengan responden yang memiliki persepsi 
hambatan yang kecil dalam melakukan perilaku SADARI. Menurut teori Health Belief Model tindakan akan dipengaruhi oleh hambatan dan manfaat. Jika responden merasa tidak memiliki hambatan, namun ia tidak merasakan manfaat maka ia akan malas dalam mengambil suatu tindakan. Begitu pula sebaliknya. Individu mungkin merasakan manfaat terhadap suatu perilaku tertentu tetapi pada saat yang sama mereka juga mungkin merasakan hambatan.

Hasil penelitian ini menunjukkan bahwa persepsi kerentanan, keseriusan, manfaat dan hambatan tidak terdapat hubungan yang signifikan dengan perilaku SADARI pada wanita usia subur (WUS).

Menurut Walgito (2010), responden yang mendapatkan stimulus yang sama tentang kanker payudara dan SADARI pasti akan mengolah stimulus tersebut sesuai dengan karakteristik individual responden, sehingga akan menghasilkan perilaku SADARI yang berbeda. Notoatmodjo (2012) menyatakan faktor penentu atau determinan perilaku manusia sulit untuk dibatasi karena perilaku merupakan resultan dari berbagai faktor, baik internal maupun eksternal (lingkungan).

Setelah dilakukan analisis diperoleh hasil bahwa variabel yang paling berpengaruh terhadap perilaku SADARI adalah tingkat pengetahuan $(p=0,003)$ dan dukungan sosial ( $p$ 0,033). Jadi responden yang memiliki tingkat pengetahuan baik berpeluang 6,1 kali lebih besar untuk melakukan perilaku SADARI dibandingkan dengan responden yang memiliki tingkat pengetahuan kurang. Responden yang ada dukungan sosial memiliki peluang 11,8 kali lebih besar untuk melakukan perilaku SADARI dibandingkan dengan responden yang tidak ada dukungan sosial. Hasil analisis juga menunjukkan sebesar $\quad 30,1 \% \quad$ kontribusi variabel pengetahuan dan dukungan sosial terhadap perilaku SADARI.

Pada umumnya tingkat pengetahuan yang tinggi atau mendapat dukungan sosial yang bersumber dari keluarga maupun orang yang dianggap penting dapat mendorong seseorang untuk berperilaku. Jadi untuk meningkatkan pengetahuan dapat dilakukan melalui pemberian KIE tentang SADARI secara optimal dan untuk dukungan sosial dapat dilakukan melalui peer group bersama teman ataupun keluarga.

\section{SIMPULAN}

Hasil penelitian yang dilakukan pada WUS menunjukkan variabel karakteristik sosiodemografi (umur, pendidikan), persepsi risiko menderita kanker payudara (kerentanan), persepsi keseriusan kanker payudara, persepsi manfaat perilaku SADARI dan persepsi hambatan melakukan perilaku SADARI tidak memiliki hubungan terhadap perilaku SADARI WUS, sedangkan variabel tingkat pengetahuan dan dukungan sosial (keluarga, teman) memiliki hubungan terhadap perilaku SADARI WUS.

\section{DAFTAR PUSTAKA}

Darmasari, T. (2016). Hubungan Tingkat Pendidikan dan Pengetahuan WUS tentang Deteksi Dini Kanker Payudara dengan Perilaku Pemeriksaan Payudara Sendiri Di Kelurahan Tambak Rejo Kecamatan Gayamsari Kota Semarang, Available:http://repository.unissul 
a.ac.id/4770/ (Accessed: 2017,

Januari 24).

Desanti. (2008). Persepsi Wanita Berisiko Kanker Payudara tentang Pemeriksaan Payudara Sendiri di Kota Semarang, Jawa Tengah. Jurnal Berita Kedokteran Masyarakat, 26(3): 152-161.

Dinkes, Badung. (2015). Laporan Tahunan Penyakit Tidak Menular Dinas Kesehatan Kabupaten Badung 2015. Tidak dipublikasi.

Dinkes, Provinsi Bali. (2015). Profil Dinas Kesehatan Provinsi Bali 2015.

Bali: Dinkes Provinsi Bali.

Melda, S. (2008). Kanker Payudara Bukan Akhir Segalanya, Available: http://www.dep.kes.go.id/indexph p?option=artikeldantask.viewwort ikledanarticl=289danintemid $=3$

(Accessed: 2016, Desember 15).

Notoatmodjo, S. (2007). Promosi Kesehatan dan Ilmu Perilaku. Jakarta: Rineka Cipta.

Notoatmodjo, S. (2012). Metodologi Penelitian Kesehatan. Jakarta: Rineka Cipta.

Notoatmodjo, S. (2014). Ilmu perilaku kesehatan. Jakarta: Rineka Cipta.

Nursalam. (2008). Konsep dan prinsip metodologi penelitian ilmu Keperawatan: Pedoman Skripsi,Tesis dan Instrumen Penelitian. Jakarta: Salemba Medika.

Walgito, B. (2010). Pengantar Psikologi Umum. Yogyakarta: CV. Andi Offset 